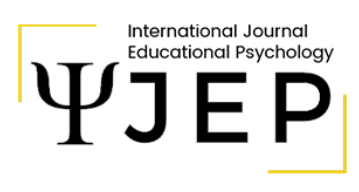

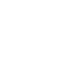

http://ijep.hipatiapress.com

\title{
Orientations to Happiness and University Students' Engagement during the COVID-19 Era: Evidence from Six American Countries
}

Maria Durón-Ramos ${ }^{1}$, Miguel Perez², Edgardo René Chacón-Andrade ${ }^{3}$

1 Instituto Tecnológico de Sonora, Mexico

${ }^{2}$ California State University, Fresno, USA

${ }^{3}$ Universidad Tecnológica, UTEC, El Salvador

Date of publication: February $24^{\text {th }}, 2022$

Edition period: February 2022 - June 2022

To cite this article: Durón-Ramos, M.F., Perez, M. \& Chacón-Andrade, E.R. (2022). Orientations to Happiness and University Students' Engagement during the COVID-19 Era: Evidence from Six American Countries. International Journal of Educational Psychology, 11(1), 50-67. doi: 10.17583/ijep.9198

To link this article: http://dx.doi.org/10.17583/ijep.9198

\section{PLEASE SCROLL DOWN FOR ARTICLE}

The terms and conditions of use are related to the Open Journal System and

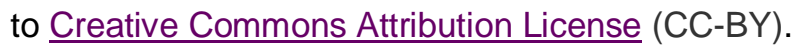




\section{Orientations to Happiness and University Students' Engagement during the COVID-19 Era: Evidence from Six American Countries}

Maria Durón-Ramos

Instituto Tecnológico de Sonora
Miguel Perez California State University, Fresno

Edgardo René Chacón-Andrade

Universidad Tecnológica, UTEC

\section{Abstract}

Positive personal characteristics such as happiness or wellbeing can motivate students to elevate their school performance in higher education. Orientation to happiness is a construct that combines three sources of happiness: pleasure, meaning, and engagement, all of which have been identified as a predictor of university student's engagement. However, most research in this area has been conducted during ideal situations or face-to-face education, and no crosscountry research has been published examining the relationship between these two concepts during the COVID-19 era, where online education was predominant. This study aimed to investigate the relation between orientation to happiness and student engagement after twelve months of distance education in a sample of 1723 students from six American countries, including the USA, Mexico, El Salvador, Colombia, Peru, and the Dominican Republic. Results indicate that university student's engagement is influenced by the orientation to happiness. Further implications of these results are discussed

Keywords: Orientation to happiness, pleasure, meaning, engagement, COVID-19 


\section{Orientaciones a la Felicidad y Compromiso Estudiantil Universitario en COVID-19: Evidencia de Seis Países Americanos}

Maria Durón-Ramos

Instituto Tecnológico de Sonora
Miguel Perez

California State University, Fresno

Edgardo René Chacón-Andrade

Universidad Tecnológica, UTEC

\section{Resumen}

Los aspectos personales positivos pueden mejorar el desempeño de los estudiantes en actividades académicas. Las orientaciones a la felicidad es un constructo que combina tres vías a la felicidad: placer, significado y compromiso. Este factor se ha descrito como un predictor del compromiso estudiantil en universitarios. Sin embargo, la relación entre estos dos conceptos necesita ser estudiada en la era de COVID-19, donde predomina la educación a distancia. El objetivo del presente estudio fue establecer la relación directa entre las orientaciones a la felicidad y el compromiso de estudiantes después de 12 meses en educación a distancia, en una muestra conformada por alumnos de seis países americanos. El instrumento fue contestado por 1723 universitarios de EUA, México, El Salvador, Colombia, Perú y la República Dominicana. Los resultados indican que el compromiso de los estudiantes está influenciado por las orientaciones a la felicidad. Las posibles implicaciones de estos resultados se presentan.

Palabras clave: Orientaciones a la felicidad, placer, significado, compromiso, COVID-19 
tudent success tends to be a reflection of university students engagement in their academic activities as measured, among other things, by their grades in the courses they take (Dogan, 2015; Jelas et al., 2016; Oriol-Granado et al., 2017). Student success is also influenced by their participation in co-curricular activities which help create stronger bonds to their academic interests. There is empirical evidence that school performance and engagement are influenced by positive personal aspects (Durón-Ramos et al., 2020) including well-being (Boulton et al., 2019), emotional intelligence (Libbrecht et al., 2014), and orientations to happiness (Sattar et al., 2017).

Previous studies have provided evidence that school performance is directly related to positive experiences (Boulton, 2019; Salanova, 2005). Durón-Ramos and colleagues (2020) found that orientation to happiness has a positive relationship to school performance; however, it is important to determine if this relationship is maintained during the online education students have received during the COVID-19 pandemic. This is important in light of research which suggests that when students have negative perceptions of online learning it diminishes their self-efficacy and motivation. Despite these preliminary results, little is known about students' engagement when studying online.

Years of distance education and online learning have demonstrated that online teaching is a viable instructional medium for students under certain circumstances. Vonderwell and Zachariah (2005) found that technology and interface characteristics, content area experience, student roles and instructional tasks, and information overload influence students' learning experiences in online learning. Additional research by Ozkan and Koseler (2009) found that system quality, service quality, content quality, learner's perspective, instructor attitudes, and supportive issues also impact student's learning in online environments. Finally, factors such as computer literacy and teaching methods, which also proven to have significant influence on elearning (Mayerova \& Rosicka, 2015).

In addition to the system characteristics necessary for successful online learning, students must also have specific characteristics that include time management, motivation, being able to communicate with others via electronic means, and those who enjoy learning via reading and writing 
(Kauffman, 2015). For these reasons, students tend to self-select for their preferred learning modality and many universities offer more than one instructional modality. To-date, there is continued debate about the pedagogical benefits of each of type of instructional modality.

The COVID pandemic, which required the closing of universities, upended education and forced many institutions of higher learning to shift all their instruction to online courses in order to maintain access to the "classroom" virtually overnight. Most universities found themselves in unfamiliar territory and without an established plan or path to online learning, the transition to this modality was not without problems (Besser et al., 2020; Schneider \& Council, 2021).

In a meta-analysis of the transition from face-to-face to online learning in medical schools in Brazil, Camargo et al. (2020) found that transitioning to remote teaching was feasible, but required a team of dedicated individuals as well as collaboration and communication between students and faculty members. Mheidly et al. (2020) found that increased screen time can lead to stress and burnout among students. In a study of 1255 students in 11 high, middle, and low-income countries, Abbasi et al. (2020) found that less than $50 \%$ of students preferred online to traditional learning. Finally, AguileraHermida (2020) found that students presented less motivation, self-efficacy, and cognitive engagement as a result of the "jump into online systems" (p.7) caused by the COVID-19 pandemic.

\section{Orientations to happiness and university student's engagement}

There are three orientations to happiness: pleasure, meaning, and engagement; together, they form a construct that has been described as the propensity of the persons in including happiness in their life from the three sources (Peterson et al., 2005). Those who pursue the three orientations experience more life satisfaction and greater well-being (Beri, 2021; Yang et al., 2016).

In this construct, pleasure maximizes gratifications and prolongs the positive feeling (O'Keefe, 2017); it is sensory and immediate and can be determined by enjoying a class in an academic context. Meaning is derived from using personal strengths and abilities for the greater good (Park et al., 2009); in the educational area, it can be experienced by obtaining a degree in a field of interest to the student. Finally, engagement orientation is the 
happiness that comes when committing and getting involved in activities (Park et al., 2009); in an academic context, it could be obtained through activity in class or during homework.

Student engagement (SE) is defined by Fredericks et al. (2004) as the tendency or propensity that students have to perform their school-related activities. SE has a direct impact on student's success (Gutierrez et al., 2017; Jelas et al., 2016), and have been proved to be a preventing factor of dropout (Lovelace et al., 2017). SE contributes not only to higher grade, but also contributes to higher graduation rates.

The literature suggests there are three components that form student engagement (Reschly \& Christenson, 2012). The first component known as behavioral engagement, is the active dimension, where students perform actions in their educational institution, such as participating in class (Lawson \& Lawson, 2013). The second component is the affective engagement, which has been described as the emotions provided by academic context (Maroco et al., 2016). Finally, cognitive engagement, is the relevance that students perceive about their school-related activities (Fredricks, 2011).

\section{The present study}

This study was conducted after 12 months of distance education during the COVID pandemic. This specific period was chosen for two primary reasons. First, it was imperative that the instruments were answered when students had adapted to the distance education, to avoid bias in the responses due to expectations or the adaptation process. Second, the inclusion of six different countries provided the opportunity to gain a broader understanding of this phenomenon.

Three hypothesis guided the current study. It was hypothesized that orientation to happiness and university student engagement were significantly different according to the country of residence (Hypothesis 1, H1). Previous studies have shown that these two constructs are influenced by the context in which people live (Kavetsos et al., 2014; Lam et al., 2012) although no studies have explored them during a time of social isolation.

The second hypothesis suggests that three orientations to happiness (pleasure, meaning, and engagement) present a positive correlation with the 
three dimensions of student's engagement (Hypothesis 2, H2) in line with investigation indicating that positive emotions influence the engagement students present (Pekrun \& Linnenbrink-Garcia, 2012). The third hypothesis predicted that orientation to happiness would directly and positively affect university student's engagement (Hypothesis 3, H3), given that this relationship has been established in traditional or classroom education (Durón-Ramos \& García-Marquez, 2018).

\section{Methods}

\section{Participants}

Data were collected from 1,723 university students in six Latin American countries. Most of the participants were female (72\%), while $27 \%$ were male, and $1 \%$ preferred not to indicate gender. The students participated voluntarily from six countries: USA (8\%), Mexico (11\%), El Salvador (21\%), Colombia (21\%), Peru (24\%), and the Dominican Republic (15\%). Age ranged from 18 to 60 years old $(M=22.34, S D=4.98)$. The students were from different semesters, including the first (1), and last (9), with a mean of $5.76(S D=2.69)$. Most participants were studying on human sciences area $(83 \%)$, the rest specified Mathematics (7\%) or other (9\%).

\section{Instruments}

Orientations to Happiness. The scale of Peterson et al. (2005) was used in its adapted form for the Mexican population (Durón-Ramos et al. 2016). It employed a Likert-type response scale of 5 points $(1=$ Completely opposite to me - $5=$ Very similar to me). The instrument evaluates the three orientations to happiness: pleasure (e.g. I love to do things that excite my senses, $\alpha=.77$ ), meaning (e.g. My life has a lasting meaning, $\alpha=.77$ ), and engagement (e.g. I am always very absorbed in what I do, $\alpha=.62$ ) with four items each. The validity of this measurement was established with confirmatory factor analysis (CFA), goodness of fit: $X^{2}=267.77$ (df $=50, p$ $=0.001)$; standardized root-mean-square residual $(\mathrm{SRMR})=0.034$; adjusted 
goodness-of-fit index $(\mathrm{AGFI})=0.96$; comparative fit index $(\mathrm{CFI})=0.96$; root mean square error of approximation $(\mathrm{RMSEA})=0.05,90 \%(\mathrm{IC}=0.044$ 0.056). Cronbach-s alpha for global scale was .84, indicating a good internal consistency.

Student's engagement. The University Student's Engagement Inventory was used (Maroco et al., 2016); this instrument has been previously implemented in Latin America populations (Durón-Ramos et al., 2020). Participants responded to the questions using a Likert-type scale of 5 points ( $1=$ Never -5 = Always $)$. The instrument evaluates student's engagement through three dimensions: behavioural (e.g. When I have doubts I ask questions and participate in debates on virtual classes, $\alpha=.75)$, emotional (e.g. I am interested in the school work I perform virtually, $\alpha=.72$ ), and cognitive (e.g. When I read a book, I question myself to make sure I understand the subject I'm reading about, $\alpha=.75$ ) with four items each. CFA confirmed the validity of this measurement with acceptable goodness of fit: $X^{2}=351.99(\mathrm{df}=50, \mathrm{p}=0.001) ; \mathrm{SRMR}=0.039 ; \mathrm{AGFI}=0.97 ; \mathrm{CFI}=0.96$; RMSEA $=0.06,90 \%(\mathrm{IC}=0.053-0.065)$.

\section{Procedure}

The study protocol was approved by the Institutional Review Board (IRB) at a university in the USA. Their approval letter along with applications were submitted to IRB committees in each of the participating institutions and subsequently all the ethics committees from the institutions participating in the study issued a document with their approval.

Data were collected using the Qualtrics platform from study participants in the six countries: USA, Mexico, El Salvador, Colombia, Peru, and the Dominican Republic. All participants provided informed consent before answering questions for the study. Data collection took place during a six week period.

Data analysis. Validity of each measure was obtained through a Confirmatory Factor Analysis; the reliability measure used was Cronbach's alpha. For the comparison of means between countries (H1), ANOVA test was performed; subsequently, a bivariate correlation matrix was calculated using Pearson coefficient $(\mathrm{H} 2)$; finally, for establishing the direct relation 
between orientation to happiness and student's engagement (H3) a structural equation model (SEM) was elaborated. Data was analyzed with SPSS and AMOS.

\section{Results}

Table 1 exhibits descriptive statistics from orientation to happiness, student engagement and their components. The means of every orientation and the global scale maintained a medium-high level $(M=3.09-3.92 ; S D=$ $.49-.81$ ), however, differences were observed by country. Students in the Dominican Republic reported higher levels of orientation to happiness in all three domains and the global measure $(M=3.62-3.92 ; S D=.50-.73)$ while students from USA reported the lower mean on the global scale of orientation to happiness $(M=3.35 ; S D=.49)$, pleasure $(M=3.34 ; S D=.66)$, and engagement $(M=3.09 ; S D=.60)$.

Descriptive statistics of student's engagement presented a larger range of means $(\mathrm{M}=2.81-4.28 ; S D=.54-.87)$, two countries exhibited high values of central tendency, El Salvador obtained higher mean on the global scale ( $M$ $=4.05 ; S D=.60)$, and in emotional engagement $(M=3.98 ; S D=.75)$ while the Dominican Republic exhibited higher level of behavioural engagement ( $M$ $=4.28 ; S D=.57)$, and cognitive engagement $(M=4.13 ; S D=.65)$. Results from ANOVA tests indicated that means among the six countries are statistically different $(p<.005)$. 
58

Duron-Ramos et al.- $O H$ and SE during COVID-19 era

Table 1.

Descriptive statistics and ANOVA results

\begin{tabular}{|c|c|c|c|c|c|c|c|c|c|}
\hline & $U S A$ & Mex & $E S$ & $\mathrm{Col}$ & Peru & $D R$ & \multicolumn{3}{|c|}{ ANOVA } \\
\hline & $\begin{array}{c}M \\
(S D)\end{array}$ & $\begin{array}{c}M \\
(S D)\end{array}$ & $\begin{array}{c}M \\
(S D)\end{array}$ & $\begin{array}{c}M \\
(S D)\end{array}$ & $\begin{array}{c}M \\
(S D)\end{array}$ & $\begin{array}{c}M \\
(S D)\end{array}$ & $F$ & $d f$ & $\mathrm{p}$ \\
\hline $\mathrm{OH}$ & $\begin{array}{l}3.35 \\
(.49)\end{array}$ & $\begin{array}{l}3.60 \\
(.58)\end{array}$ & $\begin{array}{l}3.56 \\
(.68)\end{array}$ & $\begin{array}{l}3.59 \\
(.55)\end{array}$ & $\begin{array}{l}3.61 \\
(.56)\end{array}$ & $\begin{array}{l}3.75 \\
(.50)\end{array}$ & 7.64 & 6 & .000 \\
\hline Pleasure & $\begin{array}{l}3.34 \\
(.66)\end{array}$ & $\begin{array}{l}3.61 \\
(.70)\end{array}$ & $\begin{array}{l}3.48 \\
(.81)\end{array}$ & $\begin{array}{l}3.46 \\
(.73)\end{array}$ & $\begin{array}{l}3.50 \\
(.72)\end{array}$ & $\begin{array}{l}3.62 \\
(.73)\end{array}$ & 3.15 & 6 & .004 \\
\hline Meaning & $\begin{array}{l}3.62 \\
(.69)\end{array}$ & $\begin{array}{l}3.57 \\
(.73)\end{array}$ & $\begin{array}{l}3.65 \\
(.77)\end{array}$ & $\begin{array}{l}3.68 \\
(.63)\end{array}$ & $\begin{array}{l}3.72 \\
(.66)\end{array}$ & $\begin{array}{l}3.92 \\
(.59)\end{array}$ & 6.59 & 6 & .000 \\
\hline Engagement & $\begin{array}{l}3.09 \\
(.60)\end{array}$ & $\begin{array}{l}3.61 \\
(.62)\end{array}$ & $\begin{array}{l}3.53 \\
(.72)\end{array}$ & $\begin{array}{l}3.61 \\
(.59)\end{array}$ & $\begin{array}{l}3.62 \\
(.60)\end{array}$ & $\begin{array}{l}3.70 \\
(.55)\end{array}$ & 16.67 & 6 & .000 \\
\hline SE & $\begin{array}{l}3.39 \\
(.60)\end{array}$ & $\begin{array}{l}3.69 \\
(.67)\end{array}$ & $\begin{array}{l}4.05 \\
(.60)\end{array}$ & $\begin{array}{l}3.72 \\
(.65)\end{array}$ & $\begin{array}{l}3.83 \\
(.66)\end{array}$ & $\begin{array}{l}3.99 \\
(.54)\end{array}$ & 24.83 & 6 & .000 \\
\hline Behavioural & $\begin{array}{l}3.82 \\
(.67)\end{array}$ & $\begin{array}{l}3.84 \\
(.76)\end{array}$ & $\begin{array}{l}4.16 \\
(.63)\end{array}$ & $\begin{array}{l}3.81 \\
(.74)\end{array}$ & $\begin{array}{l}3.84 \\
(.73)\end{array}$ & $\begin{array}{l}4.28 \\
(.57)\end{array}$ & 21.36 & 6 & .000 \\
\hline Emotional & $\begin{array}{l}2.81 \\
(.79)\end{array}$ & $\begin{array}{l}3.35 \\
(.87)\end{array}$ & $\begin{array}{l}3.98 \\
(.75)\end{array}$ & $\begin{array}{l}3.50 \\
(.80)\end{array}$ & $\begin{array}{l}3.70 \\
(.74)\end{array}$ & $\begin{array}{l}3.57 \\
(.83)\end{array}$ & 42.34 & 6 & .000 \\
\hline Cognitive & $\begin{array}{l}3.55 \\
(.78)\end{array}$ & $\begin{array}{l}3.87 \\
(.73)\end{array}$ & $\begin{array}{l}3.99 \\
(.75)\end{array}$ & $\begin{array}{l}3.86 \\
(.74)\end{array}$ & $\begin{array}{l}3.96 \\
(.73)\end{array}$ & $\begin{array}{l}4.13 \\
(.65)\end{array}$ & 11.13 & 6 & .000 \\
\hline
\end{tabular}

$\mathrm{OH}$, Orientations to happiness; SE Students engagement; Mex, Mexico; ES, El Salvador; Col, Colombia; DR, Dominican Republic.

A correlation matrix is presented in Table 2. All associations calculated in this study were positive and significant, with values between .51 and .64 for dimensions and the components of the same factor (orientation to happiness 
and student's engagement). It is relevant to indicate that pleasure happiness presented the lowest correlation with the three components of student engagement $(.14-.23)$, while the meaning orientation obtained the highest values $(.32$ - .39). Another interesting fact is that cognitive engagement exhibited the highest correlation coefficient with all three orientations to happiness $(.23-.39)$.

Table 2.

Correlation matrix

\begin{tabular}{|c|c|c|c|c|c|c|}
\hline & \multicolumn{3}{|c|}{ Orientation to happiness } & \multicolumn{3}{|c|}{ Student's engagement } \\
\hline & $P$ & $M$ & E & $B E$ & $E E$ & $C E$ \\
\hline P: Pleasure & - & & & & & \\
\hline M: Meaning & $.54 * *$ & - & & & & \\
\hline E: Engagement & $.54 * *$ & $.61 * *$ & - & & & \\
\hline $\begin{array}{l}\text { BE: Behavioural } \\
\text { engagement }\end{array}$ & $.16^{* *}$ & $.34 * *$ & $.26 * *$ & - & & \\
\hline EE: Emotional engagement & $.14 * *$ & $.32 * *$ & $.24 * *$ & $.60 * *$ & - & \\
\hline CE: Cognitive engagement & $.23 * *$ & $.39 * *$ & $.35 * *$ & $.64 * *$ & $.51 * *$ & - \\
\hline
\end{tabular}

The structural equation model calculated (Figure 1) exhibited good fit indices $\left[\mathrm{X}^{2}=603.50(\mathrm{df}=194, \mathrm{p}=0.001)\right.$; SRMR $=0.041$; goodness of fit index $(\mathrm{GFI})=.96 ; \mathrm{AGFI}=0.95 ; \mathrm{CFI}=0.95 ; \mathrm{RMSEA}=0.04,90 \% \mathrm{CI}(0.038-$ 0.045)] indicating that the data collected supports the theoretical model presented. The orientation to happiness (formed by: pleasure, meaning, and engagement) presents a direct significant relation (.61) with university student engagement (formed by: behavioural, emotional, and cognitive). The structural equation model explains $37 \%$ of the variance of student's engagement. 
Figure 1

Results of the SEM, Students engagement $\mathrm{R}^{2}=.37$

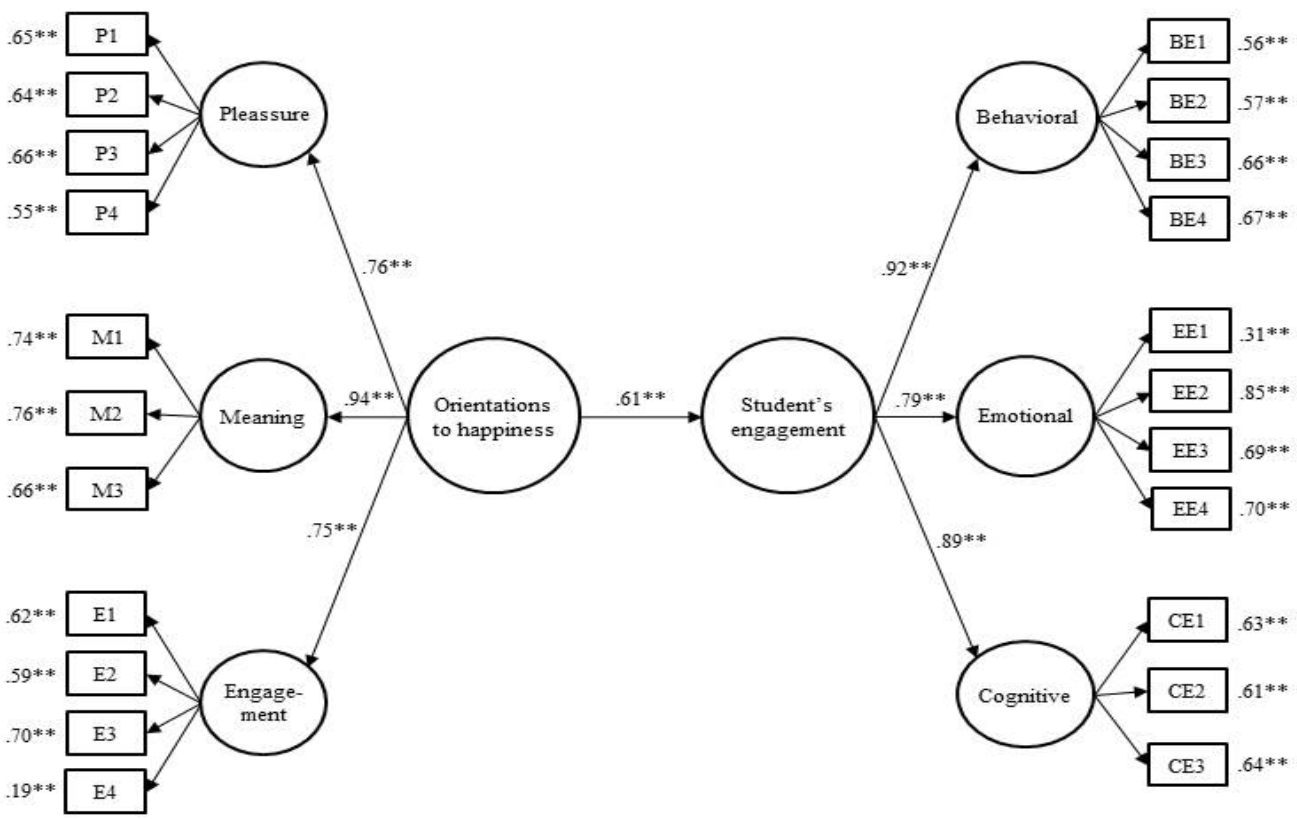

\section{Discussion}

According to the United Nations Educational, Scientific and Cultural Organization (UNESCO, 2021) almost $50 \%$ of students around the world are still dealing with closed schools almost 18 months after the onset of the global COVID-19 pandemic. The shift in education from face-to-face instruction to online education means some pupils are still participating in distance education and not always on a voluntary basis. While some researchers have focused their investigations on the negative aspects that emerge from this situation (Al-Maroof et al., 2021; Göksu et al., 2021), the present study 
focused on one positive personal aspect that could enhance university student's engagement.

Happiness has also been studied in the context of student success in institutions of higher education (Elwick \& Cannizzaro, 2017; Michalos, 2017). This variable is related to positive experiences, which translate into good school performance (Boulton, 2016; Durón-Ramos et al., 2018).

Results from this study demonstrated statistical differences on both factors analyzed among the six American countries participating in the study (H1). These results are in line with cross-cultural studies of happiness (Hornsey et al., 2018) and student engagement (Lam et al., 2015). The culture is a key factor that is related with orientations to happiness and university student's engagement.

The correlations obtained indicate that orientations to happiness and university student's engagement are two personal factors closely related (H2). The findings held true across all six countries in the study. These results are consistent with previous findings that link positive emotions and the engagement on school activities (Datu et al., 2017; Heffner \& Antaramian, 2015).

The SEM proved a direct relation between orientations to happiness and student's engagement (H3), in fact, the model explains $37 \%$ of the engagement that university students are having on online education after one year of online learning. This relation has been observed in a previous study during face-to-face education (Durón-Ramos \& García-Vázquez, 2018).

There are two limitations present in this study. First, data were collected through a self-report, where social desirability could affect some of the answers; however, results are in line with previous studies on the three hypothesis (Durón-Ramos et al., 2018; Kavetsos et al., 2014). Second, the study's cross-sectional design, where only one measure was obtained; however, we believe that this investigation could serve as a starting point for longitudinal investigations. Limitations aside, this study provides broad evidence from six American countries.

The importance of this investigation relies on the fact that it provides empirical evidence of the importance that happiness on students can provide for the academic-professional engagement in different cultural contexts. This implies that intervention or promotion of happiness among university students 
can be helpful not just for the pupils individually but could also benefit institutions of higher education (Zhong et al., 2021).

Findings from this study suggest that orientation to happiness is just one of the many positive aspects that are influencing student engagement during online higher education; other factors could be wellbeing, self-efficacy or positive emotions (Kahu et al., 2020). Two main recommendations are essential: first, it is suggested that future studies explore differences by student's field of study. Secondly, it is recommended that future studies include more variables that allow enhancing the understanding of this phenomenon; for example, the technological tool used in class, student perception of online education, and instructor experience with online education. Meyer (2014) presents a review of previous research and concludes that online videos, the use of Moodle, or including activities in social networks (such as Facebook) could increase student engagement.

\section{References}

Abassi, M.S. Ahmed, N., Batool, S., Alshahrani, A., Saeed, S., Sarfaraz, S., Alhamdan, R., Fahim, V., \& Abduljabbar, T. (2020). E-learning perceptions and satisfaction among health sciences students among the COVID-19 pandemic. Work 67, 549-556. https://doi.org/10.3233/WOR203308

Aguilera-Hermida, A.P. (2020). College students' use and acceptance of emergency online learning due to COVID-19. International Journal of Educational Research, 1, https://doi.org/10.1016/j.ijedro.2020.100011. Al-Maroof, R. S., Alhumaid, K., Akour, I., \& Salloum, S. (2021). Factors that affect e-learning platforms after the spread of COVID-19: post acceptance study. Data, 6(5), 49. https://doi.org/10.3390/data6050049

Beri, N. (2021). Orientation To Happiness Among Senior Secondary School Students Of Hilly Areas. Turkish Journal of Computer and Mathematics Education, 12(11), 7066-7075.

https://turcomat.org/index.php/turkbilmat/article/view/7232/5877

Besser, A., Flett, G. L., \& Zeigler-Hill, V. (2020). Adaptability to a sudden transition to online learning during the COVID-19 pandemic: 
Understanding the challenges for students. Scholarship of Teaching and Learning in Psychology. https://doi.org/10.1037/st10000198

Boulton, C. A., Hughes, E., Kent, C., Smith, J. R., and Williams, H. T.

(2019). Student engagement and wellbeing over time at a higher education institution. PLoS One 14:e0225770.

https://doi.org/10.1371/journal.pone.0225770

Camargo, C. P., Tempski, P. Z., Busnardo, F. F., Martins, M. A., \&

Gemperli, R. (2020). Online learning and COVID-19: a meta-synthesis analysis. Clinics (Sao Paulo, Brazil), 75, e2286.

https://doi.org/10.6061/clinics/2020/e2286

Datu, J. A. D., King, R. B., \& Valdez, J. P. M. (2017). The academic rewards of socially-oriented happiness: Interdependent happiness promotes academic engagement. Journal of School Psychology, 61, 1931. https://doi.org/10.1016/j.jsp.2016.12.004

Dogan, U. (2015). Student engagement, academic self-efficacy, and academic motivation as predictors of academic performance. Anthropologist 20, 553-561. https://doi.org/10.1080/09720073.2015.11891759

Durón-Ramos, M.F., García-Vázquez, F.I. \& Gálvez-Díaz, M.K. (2016). Traducción y validación de una escala para medir orientación a la felicidad en población mexicana [Translation and validation of a scale to measure the orientation to happiness in Mexican population]. Rev. Mex. Psicol. 2016, 468-469.

Durón-Ramos, M. F., \& García-Vázquez, F. (2018). Orientation to Happiness as Predictor of University Students'

Engagement. International Journal of Evaluation and Research in Education, 7(4), 294-298. https://doi.org/10.11591/ijere.v7.i4.pp294-298 Durón-Ramos, M. F., García-Vázquez, F. I., \& Poggio-Lagares, L. (2018). Positive psychosocial factors associated with the university student's engagement. The Open Psychology Journal,11, 292300. http://doi.org/10.2174/1874350101811010292

Durón-Ramos, M. F., Mojica-Gómez, P. A., Villamizar-Gomez, K., \& Chacón-Andrade, E. R. (2020). Impact of Positive Personal Traits on University Student Engagement in Mexico, Colombia, and El Salvador. In Frontiers in Education (Vol. 5, p.

12). https://doi.org/10.3389/feduc.2020.00012 
Elwick, A., \& Cannizzaro, S. (2017). Happiness in higher education. Higher Education Quarterly, 71(2), 204-219. https://doi.org/10.1111/hequ.12121 Fredricks, J. A., Blumenfeld, P. C., and Paris, A. H. (2004). School engagement: potential of the concept, state of the evidence. Rev. Educ. Res. 74, 59-109. https://doi.org/10.3102/0034654307400105

Fredricks, J. A. (2011). Engagement in school and out-of-school contexts: A multidimensional view of engagement. Theory into practice, 50(4), 327335.

Göksu, İ., Ergün, N., Özkan, Z., \& Sakız, H. (2021). Distance education amid a pandemic: Which psycho-demographic variables affect students in higher education?. Journal of Computer Assisted Learning. https://doi.org/10.1111/jcal.12544

Gutiérrez, M., Tomás, J. M., Barrica, J. M., and Romero, I. (2017). Influencia del clima motivacional en clase sobre el compromiso escolar de los adolescentes y su logro académico [Influence of the motivational class climate on adolescents' school engagement and their academic achievement]. Enseñ. Teach 35, 21-37. https://doi.org/10.14201/et20173512137

Heffner, A. L., \& Antaramian, S. P. (2015). The Role of Life Satisfaction in Predicting Student Engagement and Achievement. Journal of Happiness Studies, 17(4), 1681-1701. https://doi.org/10.1007/s10902-015-9665-1 Hornsey, M. J., Bain, P. G., Harris, E. A., Lebedeva, N., Kashima, E. S., Guan, Y., ... \& Blumen, S. (2018). How much is enough in a perfect world? Cultural variation in ideal levels of happiness, pleasure, freedom, health, self-esteem, longevity, and intelligence. Psychological science, 29(9), 1393-1404. https://doi.org/10.1177/0956797618768058

Jelas, Z. M., Azman, N., Zulnaidi, H., and Ahmad, N. A. (2016). Learning support and academic achievement among Malaysian adolescents: the mediating role of student engagement. Learn. Environ. Res. 19, 221-240. https://doi.org/10.1007/s10984-015-9202-5

Kahu, E. R., Picton, C., \& Nelson, K. (2020). Pathways to engagement: A longitudinal study of the first-year student experience in the educational interface. Higher Education, 79(4), 657-673. https://doi.org/10.1007/s10734-019-00429-w 
Kauffman, H. (2015). A review of predictive factors of student success in and satisfaction with online learning. Research in Learning Technology, 23. https://doi.org/10.3402/rlt.v23.26507

Kavetsos, G., Dimitriadou, M., \& Dolan, P. (2014). Measuring happiness: context matters. Applied Economics Letters, 21(5), 308-311. https://doi.org/10.1080/13504851.2013.856994

Lam, S. F., Wong, B. P., Yang, H., \& Liu, Y. (2012). Understanding student engagement with a contextual model. In Handbook of research on student engagement (pp. 403-419). Springer, Boston, MA.

Lam, S., Jimerson, S., Shin, H., Cefai, C., Veiga, F. H., Hatzichristou, C., ... Zollneritsch, J. (2015). Cultural universality and specificity of student engagement in school: The results of an international study from 12 countries. British Journal of Educational Psychology, 86(1), 137-153. https://doi.org/10.1111/bjep.12079

Lawson, M. A., \& Lawson, H. A. (2013). New conceptual frameworks for student engagement research, policy, and practice. Review of Educational Research, 83(3), 432-479. https://doi.org/10.3102/0034654313480891

Libbrecht, N., Lievens, F., Carette, B., and Côté, S. (2014). Emotional intelligence predicts success in medical school. Emotion 14, 64-73. https://doi.org/10.1037/a0034392

Lovelace, M. D., Reschly, A. L., \& Appleton, J. J. (2017). Beyond school records: The value of cognitive and affective engagement in predicting dropout and on-time graduation. Professional School Counseling, 21(1), 1096-2409. https://doi.org/10.5330/1096-2409-21.1.70

Maroco, J., Maroco, A. L., Campos, J. A. D. B., and Fredricks, J. A. (2016). University student's engagement: development of the University Student Engagement Inventory (USEI). Psicologia 29(21).

https://doi.org/10.1186/s41155-016-0042-8

Mayerova, S. H., and Rosicka, Z. (2015). E-Learning Pros And Cons: Active Learning Culture?. Social and Behavioral Sciences, 191, 958 962. https://doi.org/10.1016/j.sbspro.2015.04.702

Meyer, K. A. (2014). Student engagement in online learning: What works and why. ASHE higher education report, 40(6), 1-114.

https://doi.org/10.1002/aehe.20018

Mheidly, N., Fares, M. Y., \& Fares, J. (2020). Coping With Stress and Burnout Associated With Telecommunication and Online Learning. 
Frontiers in public health, 8, 574969.

https://doi.org/10.3389/fpubh.2020.574969

Michalos, A. C. (2017). Education, happiness and wellbeing. In Connecting the quality of life theory to health, well-being and education (pp. 277299). Springer, Cham. https://doi.org/10.1007/978-3-319-51161-0_12 O'Keefe, T. (2017). The Birth of Hedonism: The Cyrenaic Philosophers and Pleasure as a Way of Life. Ancient philosophy, 37(1), 185-192. https://doi.org/10.5840/ancientphil201737110

Oriol-Granado, X., Mendoza-Lira, M., Covarrubias-Apablaza, C. G., and Molina-López, V. M. (2017). Positive emotions, autonomy support and academic performance of university students: the mediating role of academic engagement and self-efficacy. Rev. Psicodidáctica 22, 45-53. https://doi.org/10.1387/revpsicodidact.14280

Ozkan, S. and Koseler, R. (2009). Multi-dimensional students' evaluation of e-learning systems in the higher education context: An empirical investigation. Computers \& Education, 53, 1285-1296.

https://doi.org/10.1016/j.compedu.2009.06.011

Park, N., Peterson, C., \& Ruch, W. (2009). Orientations to happiness and life satisfaction in twenty-seven nations. Journal of Positive Psychology, 4(4), 273-279. http://dx.doi.org/10.1080/17439760902933690

Pekrun, R., \& Linnenbrink-Garcia, L. (2012). Academic emotions and student engagement. In Handbook of research on student engagement (pp. 259-282). Springer, Boston, MA.

Peterson, C., Park, N. y Seligman, E. (2005). Orientations to happiness and life satisfaction: the full life versus the empty life. Journal of Happiness Studies. 2; pp: 25-41. https://doi.org/10.1007/s10902-004-1278-Z Reschly, A. L., \& Christenson, S. L. (2012). Jingle, jangle, and conceptual haziness: Evolution and future directions of the engagement construct. In Handbook of research on student engagement (pp. 3-19). Springer, Boston, MA.

Salanova, M., Martínez, I., Bresó, E., Llorens, S., and Grau, R. (2005). Bienestar psicológico en estudiantes universitarios: facilitadores y obstaculizadores del desempeño académico [Psychological well-being in university students: facilitators and impeding academic performance]. Ann Psicol.Spain 21, 170-180. https://revistas.um.es/analesps/article/view/27261 
Sattar, M. A., Rasheed, M. I., Khan, I. U., Tariq, H., and Iqbal, J. (2017). Why adaptable individuals perform better: the role of orientation to happiness. Austr. J. Career Dev. 26, 134-141.

https://doi.org/10.1177/1038416217724516

Schneider, S. L., \& Council, M. L. (2021). Distance learning in the era of COVID-19. Archives of dermatological research, 313(5), 389-390. https://doi.org/10.1007/s00403-020-02088-9

Vonderwell, S., \& Zachariah, S. (2005). Factors that influence participation in online learning. Journal of Research in Technology in Education, 38(2): 213-230. https://doi.org/10.1080/15391523.2005.10782457

Yang, Y., Li, P., Fu, X., \& Kou, Y. (2017). Orientations to happiness and subjective well-being in Chinese adolescents: The roles of prosocial behavior and internet addictive behavior. Journal of Happiness Studies, 18(6), 1747-1762. https://doi.org/10.1007/s10902-016-9794-1

Zhong, Y., Busser, J., Shapoval, V., \& Murphy, K. (2021). Hospitality and tourism student engagement and hope during the COVID-19 pandemic. Journal of Hospitality \& Tourism Education, 1-13. https://doi.org/10.1080/10963758.2021.1907197

Maria Durón-Ramos: Departament of Psychology, Guaymas Unity, ITSON, Mexico.

Miguel Perez: Department of Public Health, California State University, Fresno, USA.

Edgardo René Chacón-Andrade: Department of Psychology, Universidad Tecnológica, UTEC, El Salvador.

Contact Address: maria.duron163019@ potros.itson.edu.mx 